\title{
CAPILLARY ELECTROPHORESIS-ELECTROSPRAY-MASS SPECTROMETRY IN PEPTIDE ANALYSIS AND PEPTIDOMICS
}

\author{
Miguel Herrero, Elena Ibañez, Alejandro Cifuentes*
}

Institute of Industrial Fermentations (CSIC), Juan de la Cierva 3, 28006 Madrid, Spain.

Running title: CE-MS for peptides and peptidomics.

* corresponding author: acifuentes@ifi.csic.es Fax\# 34-91-5644853

\begin{abstract}
Abbreviations: FTICR, Fourier transform ion cyclotron resonance; GEC, $\gamma$-glutamylS-ethenyl-cysteine; IMAC, Immobilized metal affinity chromatography; MAPTAC, [3(methacryloylamino)propyl]trimethylammonium chloride; PB, Polybrene; PDMS, Poly dimethyl siloxane; PVAm, poly(vinylamine); PVS, Poly(vinyl sulfonate); Q, quadrupole; SMIL, Successive multiple ionic layer; TQ, Triple quadrupole.
\end{abstract}

Keywords: CE, CE-MS, peptides, proteomics, review. 


\begin{abstract}
In the present work, an exhaustive review of the main developments and applications of capillary electrophoresis-mass spectrometry (CE-MS) for peptide analysis is given. This review includes the use of different CE separation modes, MS analyzers, capillary coatings, preconcentration techniques, on-chip applications as well as other different multidimensional strategies for peptide analysis. Key applications are critically discussed and relevant works published from January-2000 to May-2007 are summarized including information concerning the type of sample, CE-MS parameters as well as some figures of merit of the different CE-MS procedures developed for peptide analysis and peptidomics.
\end{abstract}




\section{CONTENTS}

1. Introduction.

2. Coupling CE with MS.

2.1. Electrospray interface (ESI).

2.1.1. Sheath flow interface.

2.1.2. Sheathless interface.

2.1.3. Liquid junction.

3. MS analyzers.

4. CE separation modes for the analysis of peptides.

4.1. CZE-MS.

4.2. CEC-MS.

4.3. CIEF-MS.

5. Applications of CE-MS for peptide analysis.

5.1. CE-MS using bare silica capillaries.

5.2. CE-MS using coated capillaries.

5.3. CE-MS using on-line pre-concentration techniques.

5.4. Chip-based CE-MS applications.

5.5. Other multidimensional strategies.

6. Conclusions and future outlooks.

7. References. 


\section{INTRODUCTION}

In the "omics" era, information provided by proteomics and peptidomics is of great importance considering that proteome and peptidome, in contrast to genome, are constantly changing and related to each other through complex networks. Peptidomics is defined as the analysis of the peptide content within an organism, tissue, or cell. Technically this definition includes all peptides present in the system, including transient products of protein degradation [1].

Analysis of peptides has a huge importance in many other areas apart from peptidomics. Thus, the method commonly employed to unequivocally identify a given protein consists of obtaining its peptidic fragments, usually by well-known enzymatic reactions, followed by peptide sequencing by different analytical strategies. However, analysis of peptides in real samples (including the mentioned proteomics or peptidomics studies) is not an easy task, mainly due to their low concentration and the huge number of different peptidic sequences that can become available.

The key element of the classical proteome research combines the multidimensional separation of proteins from a complex mixture through 2D-gel electrophoresis [2] and their identification by mass spectrometry (MS) [3]. Concerning peptide analysis and peptidomics, the use of 2D-gel electrophoresis in many cases does not provide adequate separations and, therefore, other alternative methods have been developed including the use of classical Edman sequencing, HPLC-MS and, more recently, MALDI-TOF-MS and capillary electrophoresis-mass spectrometry (CE-MS) [4]. Analysis of peptides by 
these procedures has become a key analytical step and its use includes applications in clinical diagnosis, drug discovery, food analysis, etc.

CE-MS has become a powerful hyphenated technique for the separation and identification of peptides, mainly due to the particular characteristics provided by CE, that is, high efficiencies, fast analysis times, low sample and reagents consumption and versatility considering the different $\mathrm{CE}$ modes available. The increasing use of this coupling technique can be inferred by the high number of reviews published involving the use of CE-MS for proteins and peptides analysis [5-12] as well as for other biomolecules [7,13-15] or more general CE-MS developments and applications [16-23].

The aim of this work is to critically describe the main applications of CE-MS for peptide analysis and peptidomics published from January-2000 to May-2007. Thus, some representative applications are discussed trying to cover all available CE separation modes, MS analyzers and interfaces employed. Also the use of different capillary coatings, pre-concentration techniques, on-chip applications as well as other different multidimensional strategies have been included, ending with some outlooks on the future developments and applications of CE-MS in this growing area.

\section{COUPLING CE WITH MS.}

\subsection{Electrospray interface (ESI).}

Electrospray [24] is, at the moment, the interface most frequently used to carry out CEMS [25], since this soft ionization method allows the direct transfer of the analytes from 
CE to MS and provides a relatively easy way to close the electrical circuit that CE needs to operate. Besides, taking into account the MS analysis of large peptides, this ionization technique allows the formation of multi-charged ions which is very useful considering that some MS analyzers have a limited mass range. In spite of these advantages, two problems still have to be solved to successfully establish this coupling. Firstly, it is usually necessary to increase the liquid flow coming from the separation capillary (nl/min) to higher values for the formation of stable spray (1-200 $\mu \mathrm{l} / \mathrm{min})$. Secondly, an additional limitation has to be considered regarding the high volatility required of the compounds used in the background electrolyte in order to make them compatible with the spray formation. To overcome these problems, three different ESI interfaces have been developed: sheath flow, sheathless and liquid-junction interfaces, that are briefly commented below.

\subsubsection{Sheath-flow interface.}

The use of a sheath liquid in the interface was firstly proposed by Smith and co-workers [26], and basically consist on the use of three coaxial tubing that supply the analytes, the nebulization gas and the sheath liquid. The sheath liquid will have two different functions since it will act as an additional flow to enhance the spray and besides, it will close the electric contact at the outlet of the capillary acting as the second electrode. By using this set up stable sprays are obtained. Besides, it presents great versatility since a great variety of buffers can be used. Likewise, although the robustness of this set up is higher compared to other systems, the sensitivity is lower due to the dilution of the analytes by the sheath liquid. However, this is the most used interface [17] and is the only one that is commercially available. Nilsson et al. [27] carried out an interesting 
work based on the use of chemometric tools to evaluate the influence of several parameters when using a sheath flow interface. To do that, they employed several standard peptides concluding that the selection of the sheath liquid flow had a direct influence on the separation efficiency, while the nebulizing gas flow was related to the noise level generated. Interestingly, these relationships behaved similarly when comparing $25 \mu \mathrm{m}$ and $50 \mu \mathrm{m}$ capillaries, although it was possible to obtain better sensitivity with the narrower capillaries. Moreover, higher efficiencies were measured when using the $25 \mu \mathrm{m}$ ID capillaries combined with low sheath flow rates (ca. 2.0 $\mu \mathrm{l} / \mathrm{min})$.

\subsubsection{Sheathless interface.}

In this kind of interface, the electrical contact is established without the intervention of an additional flow. Instead, to close the electrical contact, different strategies have been tried, including the coating of the tip end of the capillary with a conductive metal, generally gold or silver, or with a polymer, and the introduction of a conductive wire inside the outlet of the capillary to act as the electrode. Nevertheless, the absence of commercial devices has brought about a good number of papers on this topic proposing different solutions. Thus, Waterval et al. [28] studied 5 different approaches to interface CE and MS without the use of sheath flow or nebulizing gas. These approaches basically consisted of different conductive spray tips and a T-junctions containing a gold wire as electrode. They applied these junctions to the analysis of different large peptides (insulin and cytochrome c) and concluded that the most robust interface was the T-junction, being possible to detect these peptides together with an on-line preconcentration step at amounts as low as fmol. Besides, the influence of the inner 
diameter of the spray tip on the MS signal was carefully studied, concluding that it was a critical parameter for the spray formation.

There are currently published many interesting applications on the analysis of peptides using CE-MS with a sheathless interface [29-33], demonstrating that very high sensitivities can be obtained with detection limits as low as a few attomoles [32]. However, although this kind of interface is in general more sensitive than the sheathflow interface, the problems related to the manufacturing of these sheathless devices, together with their low robustness and reproducibility have to be also considered. This fact was clearly demonstrated by Sanz-Nebot et al. [34]. A comparison between a sheathless interface based on a graphite coated tip and a sheath-flow interface revealed that the reproducibility found with the sheathless interface was, by far, lower than that determined using the sheath-flow interface, while the LODs values were similar [34]. Moreover, the formation of the spray in these sheathless devices is directly related to the presence of a strong electroosmotic flow, which in many cases can reduce spray stability or, directly, to preclude its application.

\subsubsection{Liquid junction interface.}

The third ESI interface, denominated liquid junction interface [35], is based on the use of an additional electrolyte reservoir that provides the electrical connection. In this case, the formation of the spray is obtained through an emitter capillary positioned following the outlet of the separation capillary, separated by a short space $(10-20 \mu \mathrm{m})$. The main advantage of this device is that provides independent control of the CE separation and the electrospray. On the other hand, its main drawback is the difficulty to carry out 
reproducible junctions between the emitter and separation capillary, giving frequently rise to peak broadening and loss of separation efficiency.

Foret and co-workers [36] developed a subatmospheric interface that used a liquid junction with a replaceable micro-ESI tip. The low pressure inside the ESI region leaded to sample transport through the ESI needle without the need for positive pressure at the liquid junction. Using cytochrome c tryptic digests, the authors could confirm the sensitivity improvement compared to the standard sheath flow interface, with limits of detection in the attomole range. More recently, Fanali et. al [37] employed a liquid junction interface in which the flow of the spray liquid was hydrostatically induced by gravity from a small electrolyte reservoir. Under these conditions the CE-MS system generated an efficient, reproducible and stable electrospray resulting in good sensitivity values that allowed the detection of $\mathrm{ng} / \mathrm{ml}$ of peptides. However, in authors's opinion, additional performance enhancement should still be possible with the use of narrower electrospray tips.

\section{MS analyzers.}

Concerning the analysis of peptides by CE-MS, a high variety of mass analyzers have been used, mainly single quadrupole (Q), triple quadrupole (QqQ), ion trap (IT) and time of flight (TOF), as well as other more expensive systems as quadupole-time of flight MS [38-40], Hadamard transform time-of-flight MS [41], Fourier transform ion cyclotron resonance MS (FTICR-MS) [17,42-44], etc. However, the employment of these advanced MS analyzers is not so common, obviously due to their high price and more difficult operation routine. 
Quadrupoles, due to their lower price, small size and simplicity of operation, are among the mass analyzers most employed for CE, however, their low resolution and modest sensitivity and mass range are often a drawback for peptide-related research. TOF mass analyzers are more powerful than quadrupoles regarding duty cycle (scanning speed), resolution, sensitivity and mass range, and thus, TOF analyzers are becoming more extensively employed for CE-MS of peptides [17]. However, at present, TOF analyzers are more expensive than the relatively simple quadrupoles or ion traps (IT) analyzers. Thus, ITs are also becoming widely used for CE-MS analysis of peptides since these analyzers can provide enough scanning speed and sensitivity. Besides, with IT it is also possible to carry out MS/MS experiments, which is particularly interesting for peptide sequencing.

In a work by Zürbig et al. [45], several MS analyzers combined with CE have been compared to identify polypeptidic biomarkers, including off-line CE-MALDI-TOF-MS that is out of the scope of the present review. Among the CE-ESI-MS on-line couplings studied in that work, authors demonstrated that the best results were obtained using the FTICR device, while QTOF analyzer allowed a successful sequencing of polypeptides and provided better results than simpler MS analyzers such as IT.

\section{CE SEPARATION MODES FOR THE ANALYSIS OF PEPTIDES.}

Three main modes have been employed so far to analyze peptides by CE-MS, namely, CZE, CIEF and CEC. Other modes, as MEKC and CGE are either, not compatible or not appropriate to separate peptides. 


\subsection{CZE-MS.}

Capillary zone electrophoresis (CZE, also called free solution capillary electrophoresis) is by far the most employed CE mode for CE-MS analysis of peptides. Peptides are easily separated in CZE based on their different charge/mass ratios [46] selecting MS compatible background electrolytes (BGE) usually composed of formic acid, acetic acid and/or ammonium hydroxide. In this sense, there is a huge number of CE-MS works in which this simple CZE mode is used together with a BGE at low $\mathrm{pH}(\mathrm{pH} 2-3.5)$ to separate and analyse peptides bearing a global positive charge [47-48].

\subsection{CEC-MS.}

Capillary electrochromatography (CEC) can be considered as an hybrid technique combining characteristics from HPLC and CE. Under this CE mode, analytes are separated by the same principles as in HPLC but the driving force is, in this case, the electroosmotic flow. This mode is less employed than CZE due to the complexity of fabrication and use of the CEC columns, their price and low robustness, mostly when working with real samples. On the positive side, CEC allows the use of highly MScompatible BGEs and provides the separation of neutral and charged compounds through their interaction with the stationary phase, as also demonstrated for peptides [49]. Thus, Gucek et al. [32] were able to obtain sensitivity values in the attomole range for different selected peptides coupling CEC to MS using a conductively coated tip at the end of a $\mathrm{C}_{18}$ packed CEC column. With this set-up the authors were able to obtain a stable spray without using any additional sheath liquid. 


\subsection{CIEF-MS.}

Capillary isoelectric focusing (CIEF) is a high resolution technique for the separation of proteins and peptides, as well as other amphoteric compounds. Peptides are separated in CIEF according to their $\mathrm{pI}$ values in a $\mathrm{pH}$ gradient formed by carrier ampholytes under the effect of an electric voltage. In this sense, the low volatility of these ampholytes represents a problem for the MS coupling and different approaches have been proposed to overcome this limitation [50]. For instance, in a work by Kuroda et al [51] CIEF-MS was employed to quantify human peptides. In that work, the concentration of the carrier ampholytes was optimized as a compromise between the optimum resolution and the optimum ESI-MS ionization efficiency obtaining limits of detection ten times lower than those achieved using UV detection.

\section{APPLICATIONS OF CE-MS IN PEPTIDE ANALYSIS.}

Some representative applications have been summarized in Tables 1, 2 and 3, classified according to the type of interface employed (sheath flow, sheathless and liquid junction, respectively). In each table other information is provided including sample description, MS analyzer employed, BGE used, sheath liquid nature (if any), capillary coating (when available), as well as LOD when data was provided. Finally, in Table 4, the applications including microdevices are also summarized. As can be deduced from these tables, most applications have been carried out studying peptide standards, since usually this is the type of sample selected when developing new instrumental set-ups for CE-MS $[79,86]$. 
Besides, in order to make easier the description of the multiple methods developed to analyze peptides by CE-MS in the period 2000-2007, the numerous published works on this topic will be discussed and classified below considering: i) type of capillary or coating, ii) preconcentration technique, iii) use of chips, iv) use of other multidimensional strategies.

\subsection{CE-MS using bare fused silica capillaries.}

Due to its simplicity, CE-MS applications using bare fused silica capillary are numerous as it can be deduced from Tables 1, 2 and 3. Among these applications, CE-MS has demonstrated to be a powerful technique also for peptidomics. Thus, one of the main applications of peptidomics is the biomarkers discovery. Peptides can reveal some ongoing organism malfunctions or diseases as already demonstrated [8]. Therefore, the discovery of new biomarkers that could help to the diagnosis process is of great interest. Several works have been carried out with this aim [45,60,70,74,75,98,99]. Thus, Kaiser el al. [74] were able to establish a polypeptide pattern in human fluid samples comprising more than 1000 polypeptides within 45-60 minutes analysis times by means of a CE-ESI-TOF instrument. To carry out the serum and urine analysis by CE-MS a background electrolyte containing 30\% methanol, 0.5\% formic acid and 69.5\% water (v/v/v) was selected. The same solution was employed as additional sheath flow in the interface employed. Besides, by using a specially designed software, to quickly and automatically deconvolute MS spectra, it was possible to establish normal polypeptide patterns, which significantly differed from the patterns found in patient samples (Figure 1). However, the comparison between patients affected by the same disease did not reveal any single polypeptide that could act as biomarker for these diseases. 
Nevertheless, the study of the patterns could indicate differences not only between particular diseases but also for the stage of a disease. Therefore, CE-MS was shown as as a powerful analytical tool that could greatly help to unequivocal diagnosis based on the study of polypeptide patterns [100].

One of the main uses of CE-MS in proteomics/peptidomics research, is protein identification through the analysis of the peptides produced after enzymatic digestion of the biopolymer [101], including the study of protein modifications [102]. In this regard, an important limitation arises from the frequent generation of unexpected peptidic fragments during the enzymatic digestion of any protein. To solve this problem, the use of theoretical models to simulate peptide behaviour in CE can be very useful $[47,48,66,70]$. Our group has developed a theoretical model to effectively relate the peptide sequence to their electrophoretic behaviour [47]. The effectiveness of this model was demonstrated by the fast attainment of good CZE-MS conditions for analyzing in a single run all the peptides obtained from the enzymatic digestion of a protein, as it can be observed in Figure 2. In general, good agreement was obtained between the theoretically predicted CE-MS electropherogram and the experimental separation. Thus, the simulation program not only provided with adequate background electrolyte for the separation but also with accurate information that enabled faster and easier peak assignment. This approach was later applied to the study of the equivalence of natural and recombinant enzymes, by comparing their cleavage specificities [56], demonstrating that this strategy could be a great help for other proteomic studies involving CE-MS analysis of peptides. 
Besides the aforementioned applications, the use of CE-MS together with bare silica capillaries has demonstrated to be a very useful analytical tool for studying peptide hormones [76] as well as for the characterization of therapeutically important proteins through their peptides analysis [55] or even for the quantification of natural bioactive peptides in seeds [58]. Other groups have directed their attention to the identification of microorganisms by means of peptide analysis of the proteins derived from them $[53,73]$, demonstrating that CE-MS can also be used to identify different microorganisms present in different matrices even in low amount. Besides, Erny and Cifuentes [104] developed a CE-MS mapping approach to obtain 2D maps of protein digests that allowed easy and simultaneous visual inspection of large dataset as well as to observe immediately relevant differences in closely related samples. In fact, the authors were able to differentiate in an easy way different tryptic digests from bovine, rabbit and horse cytochrome c.

The use of non-aqueous capillary electrophoresis (NACE) applied to peptidomics is not extended. Generally, peptides are relatively hydrophilic compounds that are analyzed by CE using aqueous BGEs. However, the use of organic solvents in the BGE could add some advantages to the CE-ESI-MS separation procedure, mainly increasing their volatility in the interface and the possibility to explore other interactions that do not take place in aqueous solutions. Thus, the use of organic solvents for the separation of hydrophobic peptides has already been described for the analysis of biologically active peptides from fungi [59]. In that work, using a background electrolyte composed by $12.5 \mathrm{mM}$ ammonium formate in methanol and a sheath flow interface (using as sheath liquid 2-propanol:water (1:1, v/v) containing $1 \%(\mathrm{v} / \mathrm{v})$ formic acid) it was possible to 
carry out the CE-MS identification of peptides derived from alamethicin F30 and to elucidate the amino acid sequence.

\subsection{CE-MS using coated capillaries.}

A huge number of capillary coatings have been developed up to now for CE analysis of peptides and, mostly, proteins [10,105-108]. These capillary coatings are employed to eliminate any adsorption of solutes onto the capillary wall and/or to control the electroosmotic flow. Coatings are classified in three groups: covalent, physically adsorbed and dynamic coatings. Considering the negative effect on the ionization step from the non-volatile compounds employed as dynamic coatings, their use in CE-MS is not extended [8]. Therefore, covalent and physically adsorbed coatings are the most frequently used in combination with CE-MS being neutral polymers usually the first choice. In this regard, since neutral polymers suppress the eletroosmotic flow, these neutral coatings are usually employed in CE-MS using a sheath flow interface, since, as already mentioned above, this interface is less dependant on the EOF. For instance, linear polyacrylamide has been used as coating for peptide analysis by CE-MS [67], as well as poly(vinyl alcohol) (PVA) $[37,57,73,85]$ demonstrating its suitability to prevent peptides adsorption during the analysis of these molecules. In fact, $\mathrm{Hu}$ et al., [73] showed that it was possible to identify using PVA-coated capillaries and CE-MS/MS, common pathogen microorganisms in clinical diagnosis by means of the selective identification of some of their specific peptides selected as biomarkers. The authors developed a method that included culturing followed by proteins digestion and CEMS/MS analysis in about 8 hours. This procedure allowed the identification of different pathogens in several samples [73]. 
Capillary coatings can also have an additional function as stationary phases. This was the case of a high-molecular-weight polymer made of linear poly(vinylamine) (PVAm). This polymer has been used as a coating and stationary phase conferring positive charge to the inner capillary surface to be employed in CEC [96]. The same can be applied to other compounds. For instance, different alkylaminosilyl monomers have been found useful as coatings for peptide separations in both CZE and CEC [91]. The positively charged coatings prevented effectively peptides adsorption onto the inner wall and, at the same time, by increasing the alkyl chain lengths of the used monomer, it was possible to modify their chromatographic behaviour.

Development of new coatings can enlarge the number of applications of CE-MS including analysis of peptides [80,109-111]. In this sense, Bergquist and co-workers [71] used the cationic polymer poly-LA 313 as physically adsorbed coating for the CEMS analysis of basic peptides. The coating developed was stable in a broad range of $\mathrm{pH}$ ( $\mathrm{pH} \mathrm{2-10)} \mathrm{even} \mathrm{in} \mathrm{the} \mathrm{presence} \mathrm{of} \mathrm{organic} \mathrm{modifiers.} \mathrm{A} \mathrm{sheath} \mathrm{flow} \mathrm{interface} \mathrm{was}$ employed using a solution containing $20 \%$ of $10 \mathrm{mM}$ formic acid (used as BGE) and $80 \%$ of isopropanol (v/v) was used to perform the coupling between the CE instrument and the TOF analyzer employed. Using the whole optimized procedure limits of detection down to $0.3 \mu \mathrm{M}$ for methionine-enkephalin were achieved. The same group had previously developed a coating, based on a similar polycationic polymer, that was shown to work in a shorter $\mathrm{pH}$ range (from 4 to 8) $[43,84]$.

Noncovalent bilayer coatings are physically adsorbed coatings that are prepared by successive rinsing the capillary using a positively charged polymer solution followed by 
a negatively charged polymer solution. An example of these coating, is the one formed by polybrene (PB) and poly(vinyl sulfonate) (PVS). The suitability of this PB-PVS coating in CE-MS/MS has been demonstrated analysing a protein digest [61]. The use of this coating allowed separation of peptides from cytochrome c using an acidic background electrolyte (500 mM formic acid, $\mathrm{pH}$ 2.5) an a sheath flow interface (sheath liquid ACN-water-formic acid, 75:25:0.1 v/v/v). Nevertheless, the present coating could be successfully used together with sheathless interfaces since it is possible to obtain also relatively high and $\mathrm{pH}$-independent EOFs.

\subsection{CE-MS using on-line preconcentration techniques.}

One of the most important issues regarding peptidomics by CE-MS is to get an adequate sensitivity to successfully carry out this kind of analysis, mainly given the typical low concentrations of these peptides in real samples. The good sensitivity provided by MS instruments is limited in the CE-MS coupling, due to several factors. Firstly, very low sample volumes (few $\mathrm{nl}$ ) can be injected inside the capillary without affecting the efficiency and resolution of the separation, and as a consequence, a very small amount of analyte reaches the ESI interface. Secondly, the frequent need of additional sheath liquids to obtain a stable spray diminishes the sensitivity since some dilution takes place. Third, the ionization yield and solute transfer to the MS analyzer have to be also considered since in general some loss is observed.

To overcome these limitations, different strategies to preconcentrate the sample before ESI-MS analysis have been developed and applied in the field of CE-MS of peptides. One of the most popular preconcentration procedures is sample stacking. Thus, it has 
been shown how introducing a simple $\mathrm{pH}$-mediated stacking step together with low sheath flow rates (1-2 $\mu \mathrm{l} / \mathrm{min})$ it was possible to obtain, using sheath flow interfaces, sensitivity values close to those reached with a sheathless interface providing LOD values at the low nM range for a group of standard peptides [52].

On-line pre-concentration devices based on solid phase extraction (SPE) have also been employed for peptide analysis [28,69,82,89,112]. Thus, Janini et al. [79], achieved using one of these devices LODs as low as 500 amol for a standard peptides mixture using a $20 \mu \mathrm{m}$ ID capillary. The new design developed can be observed in Figure 3. The whole device included a miniaturized micro SPE cartridge that was attached near the injection end. The whole separation procedure could be completed in less than $15 \mathrm{~min}$, and the cartridge could be easily replaced if necessary.

Other preconcentation method employed in peptidomics has been field amplified sample injection [62,72]. This technique, first introduced by Chien and Helmer [113] is based on the use of two different buffer solutions, usually at the same $\mathrm{pH}$ and different concentrations, to fill the separation capillary. Under these conditions, a drop in the migration velocity of the analytes as they reach the zone between the low conductivity sample zone and the high conductivity background electrolyte is achieved. As a result of this injection procedure, more than 3000-fold sensitivity enhancement was obtained, being possible to detect subnanomolar concentration ranges for the peptides studied [62,72]. Recently, the possibility to carry out a field amplified separation using all the capillary has been demonstrated by our group [114]. 
An additional strategy to overcome the low sensitivity problem in CE-MS is the use of transient isotachophoresis (transient-ITP). By using this technique, is possible to increase the injection volume significantly without losing efficiency and resolution. Using this technique Larsson and Lutz [67] were able to increase the injection volume up to $0.9 \mu \mathrm{l}$ while applying this concentration procedure to the qualitative analysis of tryptic digests and to the quantitative analysis of several endogenous peptides.

A more complex approach was followed by Kato el al. [64] who developed an integrated pepsin coating that enabled the on-line protein digestion, peptide separation and protein identification. The authors employed the sol-gel technology to photopolymerize a small portion at the beginning of the separation capillary. Then pepsin was encapsulated into this gel matrix without losing its enzymatic activity and the resulting peptide fragments could be directly separated in the portion of the capillary where no monolith existed. To avoid peptides adsorption onto this portion, an acidic background electrolyte was used (0.5 M formic acid).

\subsection{Chip-based CE-MS applications.}

New CE-MS developments based on chips is also a growing field since miniaturization is nowadays attracting a wide attention from the scientific community. Typically, CE on a chip can provide great flexibility to combine different analytical steps, much shorter analysis times, lower sample and reagents consumption and high throughputs [115]. Simultaneously to this large interest on chip systems, new devices are being developed to couple them to MS instruments. Applications regarding on-chip CE-MS analysis of peptides are summarized in Table 4. 
Thus, one of the first on-chip CE-MS approaches was developed by Karger and coworkers [97] showing a novel design including sample inlet ports, separation channel, liquid junction to interface chip and MS and a guiding channel for the insertion of the electrospray capillary. In this case, peptides were elected to test the performance of the developed device. A diagram of this device can be observed in Figure 4. It was possible to obtain fast separations (50 seconds) in a $4.5 \mathrm{~cm}$ on-chip separation channel. A subatmospheric electrospray interface was used and LODs in the attomole region were achieved.

Other devices have been constructed combining the characteristics from microchip-CE and new coatings for peptide analysis. Dahlin at al. [94] coated with an aliphatic polyamine agent a chip device, in which an integrated ESI tips were directly fabricated by casting PDMS in a mould. Besides, a variety of different coating procedures were also evaluated for the outside of the emitter tip. Dusting graphite on a thin unpolymerized PDMS layer followed by polymerization was proven to be the most suitable procedure, since the emitter tips showed excellent electrochemical properties and durability. With this optimized device CE-ESI-MS separations of peptides were carried out within 2 min using the hybrid PDMS chip resulting in similar efficiencies as for fused silica capillaries of the same length and thus with no measurable band broadening effects originating from the PDMS emitter.

\subsection{Other multidimensional strategies.}


Several works have been devised integrating a multidimensional approach in which CEMS is included. Multidimensional separations prior to MS detection are likely to be increasingly popular [10] since the combined use of two different techniques could not only increase the peak capacity but also increase the amount of information collected. In this section some recent works in the field of peptide analysis, including a multidimensional approach in which the latter dimension implies the use of CE and MS detection are commented, although other works including CE and MS not on-line coupled can also be found elsewhere [116].

Cao and Stults have studied the phosphorylation sites of several proteins by analyzing their enzymatic digest using on-line immobilized metal affinity chromatography (IMAC) coupled to CE-ESI-MS [88]. A selective preconcentration of the phosphorylated peptides in the IMAC step enabled the achievement of low detection limits in the subsequent CE-MS analysis. A more complex approach was followed recently by Garza and Moini [83]. These authors developed a (CE-MS/MS) ${ }^{\mathrm{n}}$ method which utilizes the most significant advantages of CE-MS/MS, including economy of sample size, fast analysis time, and high separation efficiency, to increase the sequence coverage of complex protein mixtures. Based on these characteristics, $(\mathrm{CE}-\mathrm{MS} / \mathrm{MS})^{\mathrm{n}}$ can be performed in which multiple CE-MS/MS subanalyses (injections followed by analyses) are carried out and experimental variables are manipulated during each CEMS/MS subanalysis in order to maximize sequence coverage. Following this strategy, authors could demonstrate that $(\mathrm{CE}-\mathrm{MS} / \mathrm{MS})^{\mathrm{n}}$ is a practical technique since each CEMS/MS subanalysis consumes $<10 \mathrm{~nL}$, and each CE-MS/MS subanalysis takes less than $10 \mathrm{~min}$; therefore, several subanalyses can be performed in less than $1 \mathrm{~h}$ consuming only nanoliters of the sample. 
This sequence coverage has been also explored by the direct HPLC-CE-ESI-FTICR-MS coupling [43]. In that work, authors performed the on-line LC-CE-MS coupling in a similar way as previously described by the same group $[117,118]$. Figure 5 shows a scheme of the whole set-up as well as the mechanism used to obtain the injections in the CE-MS instrument. The on-line LC-CE-ESI-FTCIR-MS was employed to study the BSA tryptic digestion product. Low detection limits were found (low pmol), while a high sequence coverage (93\%) was obtained using this multidimensional set-up. An LC-CE-MS coupling was also used to separate peptides enabling protein identification in complex mixtures [119]. In this case, authors concluded that a sheathless interface was the best choice to perform the CZE and MS coupling to analyze the fractions previously separated by RPLC.

Another different approach was followed by Dovichi and co-workers [120] coupling two different CE separation dimensions interfaced by a pepsin microreactor that allowed the first protein separation, on-line protein digestion, and second separation of the peptides generated coupled to MS. This novel set-up was tested using cytochrome and myoglobin obtaining sequence coverages of $48 \%$ and $22 \%$, respectively.

\section{CONCLUSIONS AND FUTURE OUTLOOKS.}

As it has been shown in the present work, the use of CE-MS for peptide analysis and peptidomics has increased in the last few years. As the number of applications increases each year, new developments based on this technique are also accessible. Thus, faster, more efficient, reliable and sensitive applications have been developed for CE-MS as has been shown in the present review. However, still some improvements are required 
before this technique can be used as routine. Thus, it is expected that future research will be focused on the development of more efficient and robust interfaces able to provide higher ionization yields, including new solutions to effectively interface CE and MS without the addition of sheath flows by constructing more reliable and durable sheathless interfaces. Besides, chip-CE-MS will remain of great interest as well as the multidimensional approaches. The development of new devices to interface HPLC and CE-MS in a robust and efficient way to obtain complete orthogonal separations will found also great applications possibilities. Multidimensional approaches including CEMS will be more and more developed and their number of applications will increase, including the topic of the present work, peptide analysis and peptidomics in complex real samples. In this sense, the undoubtedly great separation capacity of multidimensional techniques will find a good application area in the still growing proteomics/peptidomics field.

\section{Acknowledgements}

This study has been supported by an AGL2005-05320-C02-01 Project (Ministerio de

Educacion y Ciencia) and the S-505/AGR-0153 ALIBIRD-Project (Comunidad Autonoma de Madrid). 


\section{REFERENCES.}

[1] Fricker, L. D., Lim, J. Y., Pan, H., Che, F. Y., Mass Spec. Rev. 2006, 25, 327-344.

[2] Barnouin, K., Methods Mol. Biol. 2004, 261, 479-485.

[3] Smith, R. D., Trends Biotechnol. 2001, 20, S3-S7.

[4] Soloviev, M., Finch, P., Proteomics 2006, 6, 744-747.

[5] Kasicka, V., Electrophoresis 2003, 24, 4013-4046.

[6] Hutterer, K., Dolnik, V., Electrophoresis 2003, 24, 3998-4012.

[7] Hernández-Borges, J., Neususs, C., Cifuentes, A., Pelzing, M., Electrophoresis 2004, 25, 2257-2281.

[8] Stutz, H., Electrophoresis 2005, 26, 1254-1290.

[9] Monton, M. R. N., Terabe, S., Anal. Sci. 2005, 21, 5-13.

[10] Simpson, D. C., Smith, R. D., Electrophoresis 2005, 26, 1291-1305.

[11] Dolnik, V., Electrophoresis 2006, 27, 126-141.

[12] Kasicka, V., Electrophoresis 2006, 27, 142-175.

[13] Shamsi, S. A., Miller, B. E., Electrophoresis 2004, 25, 3927-3961.

[14] Fliser, D., Wittke, S., Mischak, H., Electrophoresis 2005, 26, 2708-2716.

[15] Moini, M., Anal. Bioanal. Chem. 2002, 373, 466-480.

[16] Cifuentes, A., Electrophoresis 2006, 27, 283-303.

[17] Schmitt-Kopplin, P., Englmann, M., Electrophoresis 2005, 26, 1209-1220.

[18] Huck, C. W., Bakry, R., Huber, L. A., Bonn, G. K., Electrophoresis 2006, 27, 2063-2074.

[19] Von Broke, A., Nicholson, G., Bayersmall, E., Electrophoresis 2001, 22, 12511266.

[20] Shen, Y., Smith, R. D., Electrophoresis 2002, 23, 3106-312. 
[21] Shamsi, S. A., Electrophoresis 2002, 23, 4036-4051.

[22] Simó, C., Barbas, C., Cifuentes, A., Electrophoresis 2005, 26, 1306-1318.

[23] Klampfl, C.W., Electrophoresis 2006, 27, 3-34.

[24] Yamashita, M., Fenn, J. B., J. Phys. Chem. 1984, 88, 4451-4459.

[25] Tomer, K. B., Chem. Rev. 2001, 101, 297-328.

[26] Smith, R. D., Barinaga, C. J., Udseth, H. R., Anal. Chem.1988, 60, 1948-1952.

[27] Nilsson, S. L., Bylund, D., Jörntén-Karlsson, M., Petersson, P., Markides, K. E., Electrophoresis 2004, 25, 2100-2107.

[28] Waterval, J. C. M., BeBestebreurje, P., Lingeman, H., Versluis, C., Heck, A. J. R., Bult, A., Underberg, W. J. M., Electrophoresis 2001, 22, 2701-2708.

[29] Kele, Z., Ferenc, G., Klement, E., Tóth, G. B., Janáky, T., Rapid Commun. Mass Spectrom. 2005, 19, 881-885.

[30] McComb, M. E., Perreault, H., Electrophoresis 2000, 21, 1354-1362.

[31] Chao, B. F., Chen, C. J., Li, F. A., Her, G. R., Electrophoresis 2006, 27, 20832090.

[32] Gucek, M., Gaspari, M., Walhagen, K., Vreeken, R. J., Verheij, E. R., van der Greef, J., Rapid Commun. Mass Spectrom. 2000, 14, 1448-1454.

[33] Musyimi, H. K., Narcisse, D. A., Zhang, X., Stryjewski, W., Soper, S. A., Murria, K. K., Anal. Chem. 2004, 76, 5968-5973.

[34] Sanz-Nebot, V., Balaguer, E., Benavente, F., Barbosa, J., Electrophoresis 2005, 26, $1457-1465$

[35] Lee, E. D., Mück, W., Henion, J. D., Covey, T. R., Biomed. Environ. Mass Spectrom. 1989, 18, 844-850.

[36] Foret, F., Zhou, H., Gang, E., Karger, B. L., Electrophoresis 2000, 21, 1363-1371. 
[37] Fanali, S., D’Orazio, G., Foret, F., Kleparnik, K., Aturki, Z., Electrophoresis 2006, 27, 4666-4673.

[38] Bindila, L., Almeida, R., Sterling, A., Allen, M., Peter-Katalinic, J., Zamfir, A., J. Mass Spec. 2004, 39, 1190-1201.

[39] Zamfir, A., Peter-Katalinic, J., Electrophoresis 2001, 22, 2448-2457.

[40] Liu, C. C., Jong, R., Covey, T., J. Chromatogr. A 2003, 1013, 9-18.

[41] Fernandez, F. M., Vadillo, J. M., Kimmel, J. R., Wetterhall, M., Markides, K., Rodriguez, N., Zare, R. N., Anal. Chem. 2002, 74, 1611-1617.

[42] Smith, R. D., Int. J. Mass Spectrom. 2000, 200, 509-544.

[43] Bergström, S. K., Dahlin, A. P., Ramström, M., Andersson, M., Markides, K. E., Bergquist, J., Analyst 2006, 131, 791-798.

[44] Gao, H. Y., Shen, Y. F., Veenstra, T. D., Harkewicz, R., Anderson, G. A., Bruce, J. E., Pasa-Tolic, L., Smith, R. D., J. Microcol. Sep. 2000, 12, 383-390.

[45] Zürbig, P., Renfrow, M. B., Schiffer, E., Novak, J., Walden, M., Wittke, S., Just, I., Pelzing, M., Neusüß, C., Theodorescu, D., Root, K. E., Ross, M. M., Mischak, M., Electrophoresis 2006, 27, 2111-2125.

[46] Cifuentes, A., Poppe, H., Electrophoresis 1997, 18, 2362-2376.

[47] Simó, C., Cifuentes, A., Electrophoresis 2003, 24, 834-842.

[48] Tessier, B., Schweizer, M., Fournier, F., Framboisier, X., Chevalot, I., Vanderesse, R., Harscoat, C., Marc, I., Food Res. Int. 2005, 38, 577-584.

[49] Klampfl, C. W., J. Chromatogr. A 2004, 1044, 131-144.

[50] Storms, H. F., van der Heijden, R., Tjaden, U. R., van der Greef, J., J. Chromatogr. B 2005, 824, 189-200.

[51] Kuroda, Y., Yukinaga, H., Kitano, M., Noguchi, T., Nemati, M., Shibukawa A., Nakagawa, T., Matsuzaki, K., J. Pharm. Biomed. Anal. 2005, 37, 423-428. 
[52] Neusüß, C., Pelzing, M., Macht, M., Electrophoresis 2002, 23, 3149-3159.

[53] Colnaghi Simionato, A. V., Simó, C., Cifuentes, A., Teixeira Lacava, P., Luiz Araújo, W., Azevedo, J. L., Carrilho, E., Electrophoresis 2006, 27, 2567-2574.

[54] Simó, C., Pérez, P., Neusüß, C., Pelzing, M., San Román, J., Gallardo, A., Cifuentes, A., Electrophoresis 2006, 27, 2250-2258.

[55] Gennaro, L. A., Salas-Solano, O., Ma, S., Anal. Biochem. 2006, 355, 249-258.

[56] Simó, C., González, R., Barbas, C., Cifuentes, A., Anal. Chem. 2005, 77, 77097716

[57] Liu, C. C., Alary, J. F., Vollmerhaus, P., Kadkhodayan, M., Electrophoresis 2005, 26, 1366-1375.

[58] Arias, M., Simó, C., Ortiz, L. T., de los Mozos-Pascual, M., Barbas, C., Cifuentes, A., Electrophoresis 2005, 26, 2351-2359.

[59] Psurek, A., Neususs, C., Degenkolb, T., Brückner, H., Balaguer, E., Imhof, D., Scriba, G. K. E., J. Peptide Sci. 2006, 12, 279-290.

[60] Wittke, S., Fliser, D., Haubitz, M., Bartel, S., Krebs, R., Hausadel, F., Hillmann, F., Golovko, I., Koester, P., Haller, H., Kaiser, T., Mischak, H., Weissinger, E. M., J. Chromatogr. A 2003, 1013, 173-181.

[61] Catai, J. R., Sastre Toraño, J., de Jong, G. J., Somsen, G. W., Electrophoresis 2006, 27, 2091-2099.

[62] Monton, M. R. N., Terabe, S., J. Chromatogr. A 2004, 1032, 203-211.

[63] De Boni, S., Neusüß, C., Pelzing, M., Scriba, G. K. E., Electrophoresis 2003, 24, 874-882.

[64] Kato, M., Sakai-Kato, K., Jin, H. M., Kubota, K., Miyano, H., Toyo’oka, H., Dulay, M. T., Zare, R. N., Anal. Chem. 2004, 76, 1896-1902. 
[65] Benavente, F., van der Heijden, U., Tjaden, U. R., van der Greef, J., Hankemeier, T., Electrophoresis 2006, 27, 4570-4584.

[66] Simó, C., López Soto-Yarritu, P., Cifuentes, A., Electrophoresis 2002, 23, 22882295.

[67] Larsson, M., Mareike Lutz, E. S., Electrophoresis 2000, 21, 2859-2865.

[68] Sanz-Nebot, V., Benavente, F., Hernández, E., Barbosa, J., Anal. Chim. Acta 2006, 577, 68-76

[69] Benavente, F., Vescina, M. C., Hernández, E., Sanz-Nebot, V., Barbosa, J., Guzman, N. A., J. Chromatogr. A 2007, 1140, 205-212.

[70] Benavente, F., Balaguer, E., Barbosa, J., Sanz-Nebot, V., J. Chromatogr. A 2006, 1117, 94-102.

[71] Puerta, A., Axen, J., Söderberg, L., Bergquist, J., J. Chromatogr. B 2006, 838, $113-121$.

[72] Yang, Y., Boysen, R. I., Hearn, M. T. W., Anal. Chem. 2006, 78, 4752-4758.

[73] Hu, A., Chen, C.T., Tsai, P.J., Ho, Y. P., Anal. Chem. 2006, 78, 5124-5133.

[74] Kaiser, T., Wittke, S., Just, I., Krebs, R., Bartel, S., Fliser, D., Mischak, E., Weissinger, E. M., Electrophoresis 2004, 25, 2044-2055.

[75] Kaiser, T., Hermann, A., Kielstein, J. T., Wittke, S., Bartel, S., Krebs, R., Hausadel, F., Hillmann, M., Golovko, I., Koester, P., Haller, H., Weissinger, E. M., Fliser, D., Mischak, H., J. Chromatogr. A 2003, 1013, 157-171.

[76] Sanz-Nebot, V., Benavente, F., Balaguer, E., Barbosa, J., Electrophoresis 2003, 24, 883-891.

[77] Hu, A., Tsai, P. J., Ho, Y. P., Anal. Chem. 2005, 77, 1488-1495.

[78] Mischak, H., Kaiser, T., Walden, M., Hillmann, M., Wittke, S., Herrmann, A., Knueppel, S., Haller, H., Fliser, D., Clinical Sci. 2004, 107, 485-495. 
[79] Janini, G. M., Conrads, T. P., Wilkens, K. L., Issaq, H. J., Veenstra, T. D., Anal. Chem. 2003, 75, 1615-1619.

[80] Sassi, A. P., Andel, F., Bitter, A. H. L., Brown, M. P. S., Chapman, R. G., Espiritu, J., Greenquist, A. C., Guyon, I., Horchi-Alegre, M, Stults, K. L., Winright, A., Heller, J. C., Stults, J. T., Electrophoresis 2005, 26, 1500-1512.

[81] Samskog, J., Wetterhall, M., Jacobsson, S., Markides, K., J. Mass Spectrom. 2000, 35, 919-924.

[82] Waterval, J. C. M., Hommels, G., Teeuwsen, J., Bult, A., Lingeman, H., Underberg, W. J. M., Electrophoresis 2000, 21, 2851-2858.

[83] Garza, S., Moini, M., Anal. Chem. 2006, 78, 7309-7316.

[84] Ullsten, S., Zuberovic, A., Wetterhall, M., Hardenborg, E., Markides, K. E., Bergquist, J., Electrophoresis 2004, 25, 2090-2099.

[85] Trapp, O., Pearce, E. W., Kimmel, J. R., Yoon, O. K., Zuleta, I. A., Zare, R. N., Electrophoresis 2005, 26, 1358-1365.

[86] Whitt, J. T., Moini, M., Anal. Chem. 2003, 75, 2188-2191.

[87] Bindila, L., Zamfir, A., Peter-Katalinic, J., J. Sep. Sci. 2002, 25, 1101-1111.

[88] Cao, P., Stults, J. T., Rapid Commun. Mass Spectrom. 2000, 14, 1600-1606.

[89] Janini, G. M., Zhou, M., Yu, L. R., Blonder, J., Gignac, M., Conrads, T. P., Issaq, H. J., Veenstra, T. D., Anal. Chem. 2003, 75, 5984-5993.

[90] Ivanov, A. R., Horváth, C., Karger, B. L., Electrophoresis 2003, 24, 3663-3673.

[91] Johannesson, N., Wetterhall, M., Markides, K. E., Bergquist, J., Elecrophoresis 2004, 25, 809-816.

[92] Tachibana, Y., Otsuka, K., Terabe, S., Arai, A., Suzuki, K., Nakamura, S., J. Chromatogr. A 2004, 1025, 287-296. 
[93] Tachibana, Y., Otsuka, K., Terabe, S., Arai A., Suzuki, K., Nakamura, S., J. Chromatogr. A 2003, 1011, 181-192.

[94] Dahlin, A. P., Wetterhall, M., Liljegren, G., Bergström, S. K., Andrén, P., Nyholm, L., Markides, K. E., Bergquist, J., Analyst 2005, 130, 193-199.

[95] Zhang, B., Foret, F., Karger, B. L., Anal. Chem. 2001, 73, 2675-2681.

[96] Chen, Z., Boggess, B., Chang, H. S., J. Mass Spectrom. 2007, 42, 244-253.

[97] Zhang, B., Foret, F., Karger, B.L., Anal. Chem. 2000, 72, 1015-1022.

[98] Kolch, W., Neusüß, C., Pelzing, M., Mischak, H., Mass Spectrom. Rev. 2005, 24, 959- 977.

[99] Schiffer, E., Mischak, H., Novak, J., Proteomics 2006, 20, 5614-4527.

[100] Wittke, S., Mischak, H., Walden, M., Kolch, W., Rädler, T., Wiedemann, K., Electrophoresis 2005, 26, 1476-1487.

[101] Yoo, C., Pal, M., Miller, F. R., Barder, T. J., Huber, C., Lubman, D. M., Electrophoresis 2006, 27, 2126-2138.

[102] Kim, J., Zand, R., Lubman, D. M., Electrophoresis, 2002, 23, 782-793.

[103] Tessier, B., Blanchard, F., Vanderesse, R., Harscoat, C., Marc, I., J. Chromatogr. A 2004, 1024, 255-266.

[104] Erny, G. L., Cifuentes, A., Electrophoresis 2007, 28, 1335-1344.

[105] Righetti, P. G., Gelfi, C., Verzola, B., Castelletti, L., Electrophoresis 2001, 22, 603-611.

[106] Liu, C. Y., Electrophoresis 2001, 22, 612-628.

[107] Cifuentes, A., Canalejas, P., Diez-Masa, J. C., J. Chromatogr. A 1999, 830, 423438.

[108] Gonzalez, N., Elvira, C., San Roman, J., Cifuentes, A., J. Chromatogr. A 2003, 1012, 95-101. 
[109] Yeung, K. K. C., Kiceniuk, A.G., Li, L., J. Chromatogr. A 2001, 931, 153-162.

[110] Lai, C. C., Her, G. R., Rapid Commun. Mass Spectrom. 2000,14, 2012-2018.

[111] Amon, S., Plematl, A., Rizzi, A., Elecctrophoresis 2006, 27, 1209-1219.

[112] Sandra, K., Lynen, F., Devreese, B., Van Beeumen, J., Sandra, P., Anal. Bioanal. Chem. 2006, 385, 671-677.

[113] Chien, R. L., Helmer, J. C., Anal. Chem. 1991, 63, 1354-1361.

[114] Erny, G. L., Cifuentes, A., Anal. Chem. 2006, 78, 7557-7562.

[115] Dolnik, V., Liu, S., J. Sep. Sci. 2005, 28, 1994-2009.

[116] Zhou, F., Johnston, M. V., Anal. Chem. 2004, 76, 2734-2740.

[117] Bergström, S. K., Samskog, J., Markides, K. E., Anal. Chem. 2003, 75, 54615467.

[118] Nilsson, S., Wetterhall, M., Bergquist, J., Nyholm, L., Markides, K. E., Rapid Commun. Mass Spectrom. 2001, 15, 1997-2000.

[119] Janini, G. M., Chan, K. C., Conrads, T. P., Issaq, H. J., Veenstra, T. D., Electrophoresis 2004, 25, 1973-1980.

[120] Schoenherr, R. M., Ye, M. L., Vannatta, M., Dovichi, N. J., Anal. Chem. 2007, $79,2230-2238$ 


\section{FIGURE LEGENDS}

Figure 1. CE-MS analysis of polypeptide standards (500 fmol each) (1) Aprotinin (6517.5 Da), (2) lysozyme (14313.1 Da), (3) ribonuclease (13690.3 Da), (4) EVQSKIG YGRQIIS (1732.96 Da), (5) TGSLPYSHIGSRDQIIFMVGR (2333.19 Da), (6) ELMTGELPYSHINNRDQIIFMVGR (2832.41 Da), (7) GIVLYELMTGELPYSHIN (2048.03 Da). The upper panel shows the total ion current, with the mass spectrum of the peptide GIVLYELMTGELPYSHIN shown as insert. Below, the same CE-MS run is shown in a 3-D contour-plot, with mass/charge (Y-axis) vs. time (X-axis), and the signal intensity color coded. [74]

Figure 2. Theoretically predicted CE-ESI-MS electropherogram (A) and experimental CE-ESI-MS electropherogram (B) of peptides from cytochrome c digested enzymatically. Numbers denote the peptides resulting from the tryptic digestion while letters denote unexpected fragments. [47]

Figure 3. Schematic diagram of the CE capillary with on-column mSPE cartridgesheathless ESI-MS interface. [79]

Figure 4. Diagram of the microdevice with a subatmospheric electrospray interface developed. The expanded view shows the coupling of the ESI tip with the separation channel in the liquid junction. [97]

Figure 5. Experimental set-up of the LC-CE-ESI-FTICRMS system. Gradient packed capillary LC (id $=0.2 \mathrm{~mm}$ ) is coupled on-line to CE (id $=50 \mu \mathrm{m}$ ) via an LC-CE 
interface in PDMS. A pressure driven flow of CE electrolyte, regulated by an injection switch, ensures independence of flows (when on) and provides injections (when off). An electric field for the CE separation is achieved between the negative potential at the inlet electrode, incorporated in the CE pressure chamber, and the grounded ESI emitter. Analytes are continuously sampled into the FTICRMS detector. [43] 
Table 1. CE-ESI-MS of peptides and peptidomics using a sheathflow interface.

\begin{tabular}{|c|c|c|c|c|c|c|c|}
\hline Sample & MS & BGE & Coating & Sheath liquid & Enrichment & Sensitivity & Ref \\
\hline $\begin{array}{c}\text { Peptide } \\
\text { standards }\end{array}$ & $\mathrm{Q}$ & $\begin{array}{l}50 \mathrm{mM} \text { formic acid, } \\
0.88 \mathrm{mM} \\
\text { ammonium formate } \\
\text { (pH 2.6) }\end{array}$ & - & $\begin{array}{l}\text { methanol:10 mM } \\
\text { formic acid 70:30 }\end{array}$ & - & n.s. & [27] \\
\hline $\begin{array}{l}\text { Peptide } \\
\text { standards }\end{array}$ & IT & $\begin{array}{c}0.2-0.5 \mathrm{M} \text { formic } \\
\text { acid, } \\
10-25 \mathrm{mM} \mathrm{NH}_{4} \mathrm{OH}, \\
10 \% \mathrm{ACN}\end{array}$ & - & $\begin{array}{l}\text { Isopropanol: } \\
\text { water (50:50) }\end{array}$ & $\begin{array}{l}\text { pH-mediated } \\
\text { stacking }\end{array}$ & $\begin{array}{l}\text { LOD: } 500 \\
\text { amol (full } \\
\text { scan, } \\
\text { MS/MS) }\end{array}$ & [52] \\
\hline $\begin{array}{l}\text { Siderophores } \\
\text { peptides }\end{array}$ & IT & $\begin{array}{c}100 \mathrm{mmol} / \mathrm{L} \\
\text { ammonium } \\
\text { bicarbonate (pH 8.0) }\end{array}$ & - & $\begin{array}{c}\text { methanol: } \mathrm{H}_{2} \mathrm{O} \\
25: 75 \text { with } 0.05 \%(\mathrm{v} / \mathrm{v}) \\
\text { formic acid }\end{array}$ & - & n.s. & [53] \\
\hline $\begin{array}{l}\text { Pseudopeptide } \\
\text { (DMTLT) }\end{array}$ & $\begin{array}{l}\text { IT } / \\
\text { TOF }\end{array}$ & $\begin{array}{l}46.5 \mathrm{mM} \text { ammonium } \\
\text { hydrogen carbonate } \\
\text { with } 15 \% \text { methanol, } \\
\text { (pH 10) }\end{array}$ & - & $\begin{array}{l}\text { 2-propanol } / \mathrm{H}_{2} \mathrm{O}(50: 50 \\
\mathrm{v} / \mathrm{v}) \text { (positive mode and } \\
+0.5 \% \text { acetic acid in } \\
\text { negative mode) }\end{array}$ & - & n.s. & [54] \\
\hline $\begin{array}{l}\text { Standard } \\
\text { peptides }\end{array}$ & IT & $\begin{array}{l}0.9 \mathrm{M} \text { ammonium } \\
\text { formate/formic } \\
\text { acid (pH 2.0) }\end{array}$ & - & $\begin{array}{c}\text { methanol- } \mathrm{H}_{2} \mathrm{O}(50: 50 \\
\text { v/v) with } \\
0.05 \% \mathrm{v} / \mathrm{v} \text { formic acid }\end{array}$ & - & n.s. & [47] \\
\hline Lys-C digest & IT & $\begin{array}{l}25 \mathrm{mM} \text { formic acid (pH } \\
3.5)\end{array}$ & - & $\begin{array}{l}\text { methanol/ } \mathrm{H}_{2} \mathrm{O} / \text { running } \\
\text { buffer }(80: 15: 5, \mathrm{v} / \mathrm{v} / \mathrm{v})\end{array}$ & - & n.s. & [55] \\
\hline $\begin{array}{l}\text { Peptides from } \\
\text { bovine Pepsin } \\
\text { A } \\
\end{array}$ & IT & $\begin{array}{c}0.9 \mathrm{M} \text { formic acid (pH } \\
2.0)\end{array}$ & - & $\begin{array}{l}\text { methanol- } \mathrm{H}_{2} \mathrm{O}(50: 50 \text {, } \\
\mathrm{v} / \mathrm{v}) \text { with } 0.05 \% \text { formic } \\
\text { acid }\end{array}$ & - & n.s. & [56] \\
\hline $\begin{array}{l}\text { Angiotensin I } \\
\text { and II }\end{array}$ & TQ & $\begin{array}{l}50 \mathrm{mM} \text { ammonium } \\
\text { acetate }\end{array}$ & Polyvinyl alcohol & $\begin{array}{l}\text { methanol- } \mathrm{H}_{2} \mathrm{O}(80: 20) \\
\text { with } 0.1 \% \text { formic acid }\end{array}$ & - & $100 \mathrm{fmol}$ & [57] \\
\hline
\end{tabular}




\begin{tabular}{|c|c|c|c|c|c|c|c|}
\hline & & $(\mathrm{pH} 3.0)$ & & & & & \\
\hline $\begin{array}{l}\gamma \text {-glutamyl-S- } \\
\text { ethenyl- } \\
\text { cysteine } \\
\text { (GEC) }\end{array}$ & IT & $\begin{array}{c}20 \mathrm{mM} \text { ammonium } \\
\text { hydrogen carbonate } \\
\text { (pH 7.0) }\end{array}$ & - & $\begin{array}{c}\text { methanol- } \mathrm{H}_{2} \mathrm{O}(50: 50 \\
\mathrm{v} / \mathrm{v}) \\
\text { with } 0.1 \% \mathrm{v} / \mathrm{v} \text { acetic } \\
\text { acid }\end{array}$ & - & $\begin{array}{l}\text { LOD: } 0.021 \\
\mathrm{mg} / \mathrm{mL}\end{array}$ & [58] \\
\hline $\begin{array}{l}\text { Alamethicins } \\
\text { peptides }\end{array}$ & $\begin{array}{l}\text { IT } / \\
\text { TOF }\end{array}$ & $\begin{array}{c}12.5 \mathrm{mM} \\
\text { ammonium formate in } \\
\text { methanol }\end{array}$ & - & $\begin{array}{c}\text { 2-propanol- } \mathrm{H}_{2} \mathrm{O}(1: 1 \text {, } \\
\text { v/v) with } 1 \% \\
\text { formic acid }\end{array}$ & - & n.s. & [59] \\
\hline $\begin{array}{l}\text { Human urine } \\
\text { peptides }\end{array}$ & TOF & $\begin{array}{c}0.25 \mathrm{M} \text { formic acid } \\
(20 \% \mathrm{v} / \mathrm{v} \mathrm{ACN})\end{array}$ & - & $\begin{array}{c}7: 3 \mathrm{v} / \mathrm{v} \\
\mathrm{H}_{2} \mathrm{O} / \text { isopropanol with } \\
0.5 \% \mathrm{v} / \mathrm{v} \\
\text { formic acid }\end{array}$ & - & $\begin{array}{l}25 \text { fmol } \\
\text { (for } \\
\text { standards) }\end{array}$ & [60] \\
\hline $\begin{array}{l}\text { Enkephalin } \\
\text { peptides }\end{array}$ & IT & $\begin{array}{c}500 \mathrm{mM} \text { formic acid } \\
(\mathrm{pH} \mathrm{2.5)}\end{array}$ & $\begin{array}{c}\text { Polybrene } \\
\text { (PB) and } \\
\text { poly(vinyl } \\
\text { sulfonate) (PVS) }\end{array}$ & $\begin{array}{c}\text { ACN- } \mathrm{H}_{2} \mathrm{O}-\text { formic } \\
\text { acid }(75: 25: 0.1 \mathrm{v} / \mathrm{v} / \mathrm{v})\end{array}$ & - & $\begin{array}{c}\mathrm{LOD}(\mathrm{S} / \mathrm{N}= \\
\text { 3): } 10-90 \\
\text { fmol }\end{array}$ & [61] \\
\hline $\begin{array}{c}\text { Standard } \\
\text { peptides and } \\
\text { tryptic digest }\end{array}$ & IT & $\begin{array}{l}\text { 100mM ammonium } \\
\text { formate (pH 3.0) }\end{array}$ & - & $\begin{array}{c}50 \% \text { methanol, } 49 \% \\
\mathrm{H}_{2} \mathrm{O} \text { and } 1 \% \text { acetic acid }\end{array}$ & $\begin{array}{l}\text { Field enhanced } \\
\text { sample injection }\end{array}$ & $\mathrm{nM}$ & [62] \\
\hline $\begin{array}{c}\text { aspartyl } \\
\text { tripeptides }\end{array}$ & IT & $\begin{array}{c}200 \text { mM formic acid } \\
\text { (pH 2.9) }\end{array}$ & - & isopropanol: $\mathrm{H}_{2} \mathrm{O}(1: 1)$ & - & n.s. & [63] \\
\hline Protein digest & & $0.5 \mathrm{M}$ formic acid & $\begin{array}{c}\text { Pepsin coated } \\
\text { photopolymerized } \\
\text { solgel monolith }\end{array}$ & $\begin{array}{c}5 \mathrm{mM} \text { ammonium } \\
\text { acetate in } 50 \%(\mathrm{v} / \mathrm{v}) \\
\text { methanol/ } \mathrm{H}_{2} \mathrm{O}\end{array}$ & $\begin{array}{l}\text { Online protein } \\
\text { digestion }\end{array}$ & n.s. & [64] \\
\hline $\begin{array}{l}\text { Bioactive } \\
\text { peptide } \\
\text { hormones }\end{array}$ & TOF & $\begin{array}{l}50 \mathrm{mM} \text { of acetic acid } \\
\text { and } 50 \mathrm{mM} \text { of formic } \\
\text { acid (pH 2.85) }\end{array}$ & - & $\begin{array}{c}\text { 60:40 (v/v) } \\
\text { 2-propanol- } \mathrm{H}_{2} \mathrm{O} \text { with } \\
0.05 \%(\mathrm{v} / \mathrm{v}) \text { of formic } \\
\text { acid }\end{array}$ & - & n.s. & [65] \\
\hline $\begin{array}{l}\text { Standard } \\
\text { peptides }\end{array}$ & IT & $\begin{array}{l}1.3 \mathrm{mM} \text { ammonium } \\
\text { acetate/acetic acid and }\end{array}$ & - & $\begin{array}{l}\text { methanol- } \mathrm{H}_{2} \mathrm{O}(50: 50 \\
\mathrm{v} / \mathrm{v}) \text { containing } 0.05 \%\end{array}$ & - & $\begin{array}{l}\text { Shown: 0.1- } \\
02 \mathrm{mg} / \mathrm{ml}\end{array}$ & [66] \\
\hline
\end{tabular}




\begin{tabular}{|c|c|c|c|c|c|c|c|}
\hline & & $\begin{array}{c}130 \mathrm{mM} \\
\text { ammonium } \\
\text { formate/formic acid } \\
(\mathrm{pH} \mathrm{2.41)}\end{array}$ & & $\begin{array}{l}\mathrm{v} / \mathrm{v} \text { formic } \\
\text { acid }\end{array}$ & & & \\
\hline $\begin{array}{l}\text { Cytochrome c } \\
\text { digest }\end{array}$ & Q & $\begin{array}{c}150 \mathrm{mM} \text { acetic acid } \\
\text { and } 55 \mathrm{mM} \text { formic acid } \\
(\mathrm{pH} \mathrm{4.0)}\end{array}$ & Polyacrilamide & $\begin{array}{c}50 \% \mathrm{v} / \mathrm{v} \text { Isopropanol } \\
0.5 \% \mathrm{v} / \mathrm{v} \text { acetic } \\
\text { acid/formic acid } \\
\end{array}$ & Transient ITP & $\begin{array}{l}\text { Shown: } 14 \\
\text { nmol/l }\end{array}$ & [67] \\
\hline $\begin{array}{l}\text { Biomarker } \\
\text { peptides }\end{array}$ & $\begin{array}{l}\text { TOF } \\
\text { IT } \\
\text { QTOF } \\
\text { FITCR }\end{array}$ & $\begin{array}{l}\text { 30\% methanol, } 0.5 \% \\
\text { formic } \\
\text { acid }\end{array}$ & - & $\begin{array}{c}0.5 \% \mathrm{v} / \mathrm{v} \text { formic acid in } \\
\text { water }\end{array}$ & - & n.s. & [45] \\
\hline $\begin{array}{c}\text { Opioid } \\
\text { peptides }\end{array}$ & TOF & $\begin{array}{c}50 \mathrm{mM} \text { acetic acid- } \\
50 \mathrm{mM} \text { formic acid (pH } \\
3.5)\end{array}$ & - & $\begin{array}{c}60: 40 \\
\text { (v/v) 2-propanol: } \mathrm{H}_{2} \mathrm{O} \\
\text { with } 0.05 \%(\mathrm{v} / \mathrm{v}) \text { of } \\
\text { formic acid. }\end{array}$ & - & $\begin{array}{l}\text { Shown: } 200 \\
\text { ng/ml }\end{array}$ & [68] \\
\hline $\begin{array}{l}\text { Angiotensin II, } \\
\text { Leuenkephalin }\end{array}$ & $\mathrm{Q}$ & $\begin{array}{l}\mathrm{N} \text {-[carbamoylmethyl]- } \\
\text { 2-aminoethanesulfonic } \\
\text { acid (ACES) (pH 7.4) }\end{array}$ & - & $\begin{array}{c}20 \mathrm{mM} \text { of acetic acid in } \\
50: 50(\mathrm{v} / \mathrm{v}) \\
\text { methanol: } \mathrm{H}_{2} \mathrm{O}\end{array}$ & SPE & LOD: $\mathrm{ng} / \mathrm{ml}$ & [69] \\
\hline $\begin{array}{l}\text { Bradykinin, } \\
\text { substance P, } \\
\text { glutation }\end{array}$ & IT & $\begin{array}{l}50 \mathrm{mM} \text { of acetic acid } \\
\text { and } 50 \mathrm{mM} \text { of formic } \\
\text { acid (pH 2.5) }\end{array}$ & - & $\begin{array}{c}80: 20 \mathrm{v} / \mathrm{v} \text { methanol/ } \\
\mathrm{H}_{2} \mathrm{O} \text { with } 0.1 \% \mathrm{v} / \mathrm{v} \text { of } \\
\text { acetic acid (positive } \\
\text { ionization) or } 60: 40 \mathrm{v} / \mathrm{v} \\
\text { isopropanol } / \mathrm{H}_{2} \mathrm{O} \text { with } \\
0.5 \% \mathrm{v} / \mathrm{v} \text { of } \\
\text { ammonia (negative } \\
\text { ionization) }\end{array}$ & - & $\begin{array}{l}\text { LOD: } 1 \text { - } 10 \\
\text { mg/L. }\end{array}$ & [70] \\
\hline $\begin{array}{l}\text { Standard } \\
\text { peptides }\end{array}$ & TOF & 10mM formic acid. & $\begin{array}{l}\text { poly-LA 313, } \\
\text { polymer }\end{array}$ & $\begin{array}{c}20 \% \text { of } 10 \mathrm{mM} \text { formic } \\
\text { acid and } 80 \% \text { of } \\
\text { isopropanol }\end{array}$ & - & $\begin{array}{l}\text { LOD: } 0.3- \\
2.5 \mu \mathrm{M}\end{array}$ & [71] \\
\hline Standard & IT & $20 / 40 / 40$ & - & $0.1 \%$ formic acid in & Stacking & Shown: $10^{-9}$ & [72] \\
\hline
\end{tabular}




\begin{tabular}{|c|c|c|c|c|c|c|c|}
\hline $\begin{array}{l}\text { peptides and } \\
\text { Cytochrome c } \\
\text { digests } \\
\end{array}$ & & $\begin{array}{c}\text { acetonitrile/100 mM } \\
\text { HCOONH}_{4}, \mathrm{pH} \\
\text { 3.0/water }(\mathrm{v} / \mathrm{v} / \mathrm{v}) \\
\end{array}$ & & $\begin{array}{c}50 \% \\
\text { Methanol (v/v) }\end{array}$ & & M) & \\
\hline $\begin{array}{l}\text { Bacteria } \\
\text { peptides }\end{array}$ & IT & $\begin{array}{c}10 \text { mM ammonium } \\
\text { acetate (70\%) and } 10 \\
\text { mM acetic acid (30\%) } \\
(\mathrm{pH} 4.8)\end{array}$ & $\begin{array}{l}\text { poly(vinyl } \\
\text { alcohol) }\end{array}$ & $\begin{array}{c}50 \% \text { Methanol with } \\
0.5 \% \\
\text { acetic acid }\end{array}$ & - & n.s. & [73] \\
\hline $\begin{array}{l}\text { Standard } \\
\text { peptides }\end{array}$ & $\mathrm{Q}$ & $\begin{array}{c}50 \mathrm{mM} \\
\text { formic acid (pH 2.75) }\end{array}$ & - & $\begin{array}{c}100 \% \text { methanol } \\
\text { with } 0.2 \% \text { formic acid }\end{array}$ & - & $\begin{array}{l}\text { LOD: } 5 \\
\text { pmol }\end{array}$ & [48] \\
\hline $\begin{array}{l}\text { Urine and } \\
\text { serum } \\
\text { polypeptides }\end{array}$ & TOF & $\begin{array}{l}30 \% \text { methanol, } 0.5 \% \\
\text { formic acid, } 69.5 \% \\
\mathrm{H}_{2} \mathrm{O}\end{array}$ & - & $\begin{array}{c}30 \% \text { methanol and } \\
0.5 \% \text { formic acid }\end{array}$ & - & $\begin{array}{l}\text { Shown: } 500 \\
\text { fmol }\end{array}$ & [74] \\
\hline $\begin{array}{l}\text { Hemodialysis } \\
\text { fluids peptides }\end{array}$ & TOF & $\begin{array}{l}\text { 30\% methanol, } 0.5 \% \\
\text { formic acid, } 69.5 \% \\
\text { water }\end{array}$ & - & $\begin{array}{l}\text { 30\% methanol, } 0.5 \% \\
\text { formic acid }\end{array}$ & - & n.s. & [75] \\
\hline $\begin{array}{l}\text { Peptide } \\
\text { hormones }\end{array}$ & TOF & $\begin{array}{c}50 \mathrm{mM} \text { of } \\
\text { acetic acid and } 50 \mathrm{mM} \\
\text { of formic acid (pH } \\
2.85)\end{array}$ & - & $\begin{array}{l}\text { 60\% 2-propanol, } 0.05 \% \\
\text { v/v formic acid }\end{array}$ & - & $\begin{array}{l}\text { LOD: } 1 \text { to } 4 \\
\mu \mathrm{g} / \mathrm{mL} .\end{array}$ & [76] \\
\hline $\begin{array}{l}\text { Angiotensin } \\
\text { peptides }\end{array}$ & QTOF & & - & Methanol & - & $\begin{array}{c}\text { Shown: } 10^{-4} \\
\mathrm{M}\end{array}$ & [40] \\
\hline $\begin{array}{l}\text { Microbial } \\
\text { marker } \\
\text { peptides }\end{array}$ & IT & $\begin{array}{c}10 \text { mM ammonium } \\
\text { acetate }(70 \%) \text { and } 10 \\
\text { mM acetic acid (30\%) } \\
(\mathrm{pH} 4.8)\end{array}$ & $\begin{array}{l}\text { poly(vinyl } \\
\text { alcohol) }\end{array}$ & $\begin{array}{c}50 \% \text { methanol } \\
\text { containing } 0.5 \% \text { acetic } \\
\text { acid }\end{array}$ & - & n.s. & [77] \\
\hline $\begin{array}{l}\text { Angiotensin, } \\
\text { transferrin }\end{array}$ & & Carrier ampholytes & - & $\begin{array}{c}\mathrm{H}_{2} \mathrm{O} / \text { methanol/acetic } \\
\text { acid (50/49/1) }\end{array}$ & - & $\begin{array}{l}\text { LOD: } \\
0.22 \mu \mathrm{M}\end{array}$ & [51] \\
\hline Protein digests & IT & & $\begin{array}{c}\text { siloxanediol- } \\
\text { polyacrylamide }\end{array}$ & $\begin{array}{c}0.5 \% \text { acetic acid in } \\
\text { methanol/ } \mathrm{H}_{2} \mathrm{O}(80 / 20 \text {, } \\
\mathrm{v} / \mathrm{v})\end{array}$ & - & n.s. & [50] \\
\hline
\end{tabular}




\begin{tabular}{|l|c|c|c|c|c|c|c|}
\hline Polypeptides & n.s. & $\begin{array}{c}30 \%(\mathrm{v} / \mathrm{v}) \\
\text { methanol/0.5\%(v/v) } \\
\text { formic acid in } \mathrm{H}_{2} \mathrm{O}\end{array}$ & - & $\begin{array}{c}30 \%(\mathrm{v} / \mathrm{v}) \\
\text { methanol/0.5\%(v/v) } \\
\text { formic acid in } \mathrm{H}_{2} \mathrm{O}\end{array}$ & - & n.s. & {$[78]$} \\
\hline
\end{tabular}

n.s.: data not shown in the reference 
Table 2. CE-ESI-MS of peptides and peptidomics using a sheathless interface.

\begin{tabular}{|c|c|c|c|c|c|c|}
\hline Sample & MS & BGE & Coating & Enrichment & Sensitivity & Ref \\
\hline Peptide standards & TQ & 1-5\% acetic acid & - & - & LOD: ca. 115 fmol & [30] \\
\hline $\begin{array}{c}{\left[\mathrm{Glu}^{1}\right]-} \\
\text { fibrinopeptide B }\end{array}$ & IT & $1 \mathrm{M}$ acetic acid (pH 2.4) & - & - & $\begin{array}{c}\mathrm{LOD}(\mathrm{S} / \mathrm{N}=5): 900 \\
\text { amol }\end{array}$ & [79] \\
\hline $\begin{array}{l}\text { Human serum } \\
\text { peptides }\end{array}$ & TOF & $\begin{array}{c}60 \mathrm{mM} \\
\text { acetic acid in 20\% } \\
\text { methanol (pH 3.2) }\end{array}$ & MAPTAC & Stacking & $\begin{array}{c}\text { LOD: } \begin{array}{c}10-100 \mathrm{nM} \text { in } \\
\text { serum }\end{array}\end{array}$ & [80] \\
\hline $\begin{array}{l}\text { Angiotensin } \\
\text { II, Gonadorelin }\end{array}$ & TQ & $\begin{array}{c}25 \mathrm{mM} \text { formic acid in } 5 \% \\
\mathrm{v} / \mathrm{v} \text { methanol- } \mathrm{H}_{2} \mathrm{O}(\mathrm{pH} \\
2.3)\end{array}$ & $\begin{array}{l}\text { 3-aminopropyl- } \\
\text { triethoxysilane }\end{array}$ & $\begin{array}{l}\text { Off-line SPE } \\
\text { On-line } \\
\text { preconcentration }\end{array}$ & LOD: pM & [28] \\
\hline Standard peptides & TOF & $\begin{array}{c}16 \mathrm{mM} \text { acetic } \\
\text { acid-ammonium acetate } \\
(\mathrm{pH} \mathrm{3)}\end{array}$ & MAPTAC & - & n.s. & [81] \\
\hline $\begin{array}{l}\text { Angiotensin II, } \\
\text { insulin, } \\
\text { gonadorelin }\end{array}$ & TQ & $\begin{array}{l}25 \mathrm{mM} \text { formic acid in 5\% } \\
\text { methanol }\end{array}$ & - & $\begin{array}{c}\text { On-line } \\
\text { preconcentration }\end{array}$ & Shown: $1 \mathrm{ng} / \mathrm{ml}$ & [82] \\
\hline Peptide standards & FITCR & $\begin{array}{c}10 \mathrm{mM} \\
\text { acetic acid/ ACN 75:25 }\end{array}$ & PolyE-323 & LC-CE coupling & $\begin{array}{c}\text { Limit of identification } \\
0.3 \mu \mathrm{M}\end{array}$ & [43] \\
\hline Protein digest & QTOF & $\begin{array}{l}0.05 \% \text { Polybrene in } 0.1 \% \\
\text { acetic acid }\end{array}$ & - & - & Shown: $200 \mathrm{fmol}$ & [83] \\
\hline BSA digest & TOF & $\begin{array}{c}5 \mathrm{mM} \text { acetic acid in } 25 \% \\
\text { ACN. }\end{array}$ & PolyE-323 & - & Shown: 2 fmol & [84] \\
\hline $\begin{array}{l}\text { Angiotensin, } \\
\text { Substance P }\end{array}$ & TOF & $\begin{array}{c}1: 150 \mathrm{mM} \text { formic } \\
\text { acid/ammonium acetate } \\
\text { buffer (pH 2.8) and } \\
\text { methanol }\end{array}$ & $\begin{array}{l}\text { poly(vinyl } \\
\text { alcohol) }\end{array}$ & - & n.s. & [85] \\
\hline Cytochrome c & IT & $0.1 \%$ acetic acid & Aminopropyl & - & n.s. & [86] \\
\hline
\end{tabular}




\begin{tabular}{|c|c|c|c|c|c|c|}
\hline digest & & & trimethoxysilane & & & \\
\hline $\begin{array}{l}\text { Extracellular } \\
\text { matrix peptides }\end{array}$ & TOF & $\begin{array}{c}0.5 \mathrm{M} \text { ammonium } \\
\text { formate in } \mathrm{H}_{2} \mathrm{O} / \text { methanol } \\
(40 / 60 ; \mathrm{v} / \mathrm{v})(\mathrm{pH} 2.2)\end{array}$ & - & - & n.s. & [87] \\
\hline $\begin{array}{l}\text { O-glycosylated } \\
\text { peptides }\end{array}$ & QTOF & $\begin{array}{c}50 \mathrm{mM} \\
\text { aqueous }+40 \% \text { methanol } \\
\text { ammonium } \\
\text { acetate/ammonium } \\
\text { hydroxide (pH 12) }\end{array}$ & - & - & n.s. & [39] \\
\hline $\begin{array}{l}\text { a- and b-casein } \\
\text { digests }\end{array}$ & IT & $\begin{array}{c}0.1 \% \text { acetic acid } / 10 \% \\
\text { methanol solution }\end{array}$ & - & - & Shown: $500 \mathrm{fmol}$ & [88] \\
\hline Peptide standards & IT & $1.0 \mathrm{M}$ acetic acid, $\mathrm{pH} 2.4$ & - & - & LOD: $500 \mathrm{amol}$ & [89] \\
\hline Peptide standards & TOF & $\begin{array}{c}20 \mathrm{mM} \\
\text { ammonium acetate in } \\
20 \% \mathrm{v} / \mathrm{v} \text { acetonitrile (pH } \\
4.4)\end{array}$ & $\begin{array}{l}\text { Monolithic } \\
\text { column }\end{array}$ & - & n.s. & [90] \\
\hline
\end{tabular}

n.s.: data not shown in the reference 
Table 3. CE-ESI-MS of peptides using a liquid junction interface.

\begin{tabular}{|c|c|c|c|c|c|c|}
\hline Sample & MS & BGE & Coating & Enrichment & Sensitivity & Ref \\
\hline $\begin{array}{c}\text { peptide } \\
\text { standards }\end{array}$ & TOF & $\begin{array}{c}5 \mathrm{mM} \text { acetic acid with } \\
20 \% \mathrm{ACN}\end{array}$ & $\begin{array}{c}\text { N-Trimethoxysilylpropyl-N,N,N- } \\
\text { trimethylammonium chloride }\end{array}$ & & & [91] \\
\hline $\begin{array}{c}\text { bradykinin, } \\
\text { angiotensin I, } \\
\text { neurotensin, } \\
\text { Leu-enkephalin }\end{array}$ & IT & $\begin{array}{l}50 \mathrm{mM} \text { ammonium } \\
\text { formate (pH 2.8) }\end{array}$ & $\begin{array}{c}\text { polyvinyl alcohol } \\
\text { (PVA) }\end{array}$ & - & $\begin{array}{l}\text { LOD: below } \\
200 \mathrm{ng} / \mathrm{mL}\end{array}$ & [37] \\
\hline
\end{tabular}


Table 4. Peptide analysis by on-chip CE-ESI-MS.

\begin{tabular}{|c|c|c|c|c|c|c|c|}
\hline Sample & MS & BGE & Coating & Sheath liquid & Enrichment & Sensitivity & Ref \\
\hline $\begin{array}{l}\text { Standard } \\
\text { peptides }\end{array}$ & $\mathrm{Q}$ & $\begin{array}{c}50 \mathrm{mM} \text { formic acid (pH } \\
2.5)\end{array}$ & SMIL & $\begin{array}{c}\text { 50mM formic acid } \\
(\mathrm{pH} \mathrm{2.5})\end{array}$ & & & {$[92]$} \\
\hline Tripeptides & Q & $\begin{array}{c}50 \mathrm{mM} \text { acetic acid- } \\
\text { ammonium acetate buffer } \\
\text { (pH 5.7) with } 30 \%(\mathrm{v} / \mathrm{v}) \\
\text { ACN }\end{array}$ & - & $\begin{array}{c}50 \mathrm{mM} \text { acetic acid- } \\
\text { ammonium acetate } \\
\text { buffer (pH 5.7) with } \\
30 \%(\mathrm{v} / \mathrm{v}) \\
\text { ACN }\end{array}$ & Stacking & $\begin{array}{l}\text { Shown: } 100 \\
\text { ppm }\end{array}$ & [93] \\
\hline $\begin{array}{l}\text { Standard } \\
\text { peptides }\end{array}$ & TOF & $\begin{array}{c}\text { 75\% ACN, 25\% } 10 \mathrm{mM} \\
\text { acetic acid }\end{array}$ & PolyE-323 & Sheathless & - & $\begin{array}{l}\text { Shown: } 1 \\
\mu \mathrm{g} / \mathrm{ml}\end{array}$ & [94] \\
\hline Tryptic digests & IT & $\begin{array}{c}\text { aminocaproic acid/acetic } \\
\text { acid (pH 4.4) }\end{array}$ & - & $\begin{array}{c}\text { Liquid junction }(1 \% \\
(\mathrm{v} / \mathrm{v}) \text { acetic acid in } \\
50 \%(\mathrm{v} / \mathrm{v}) \\
\left.\text { methanol/ } / \mathrm{H}_{2} \mathrm{O}\right)\end{array}$ & - & n.s. & {$[95]$} \\
\hline $\begin{array}{l}\text { Peptide } \\
\text { standards }\end{array}$ & TQ & $\begin{array}{c}1 \mathrm{M} \text { acetic } \\
\text { acid }\end{array}$ & Lupamin & Sheathless & - & n.s. & {$[96]$} \\
\hline Angiotensin & IT & $\begin{array}{c}20 \text { mM 6-aminocaproic } \\
\text { acid (pH 4.4) }\end{array}$ & PVA & $\begin{array}{c}1 \% \mathrm{v} / \mathrm{v} \text { acetic acid in } \\
50 \% \mathrm{v} / \mathrm{v} \text { methanol }\end{array}$ & - & n.s. & {$[97]$} \\
\hline
\end{tabular}

n.s.: data not shown in the reference 


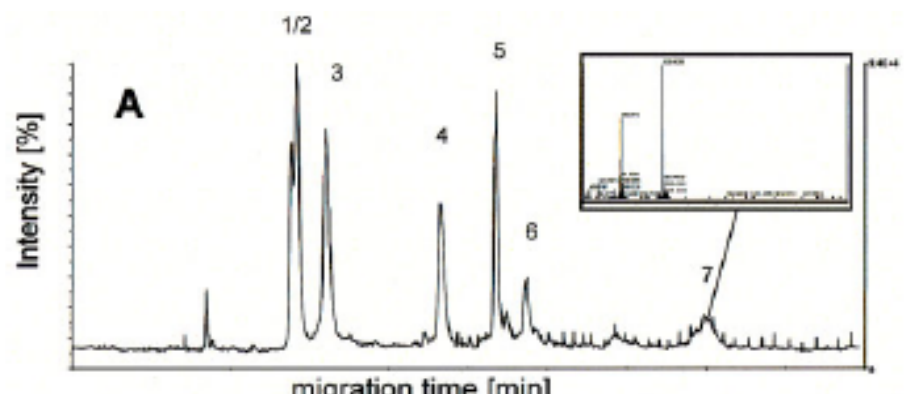

migration time [min]

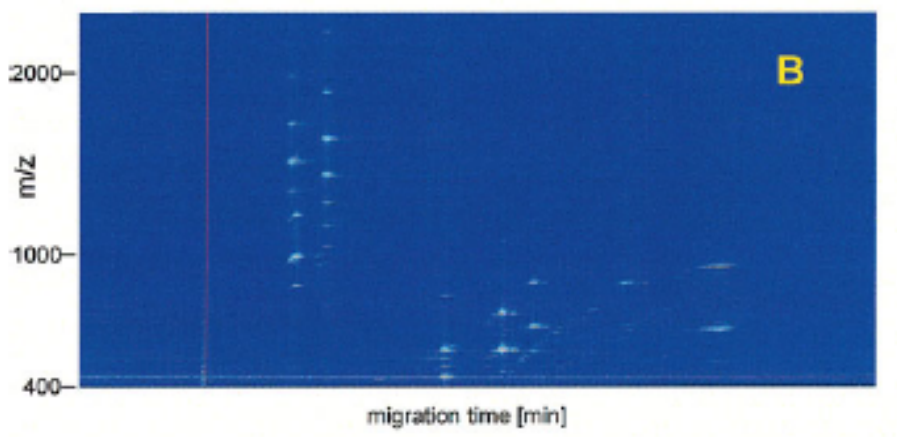

Figure 1. 

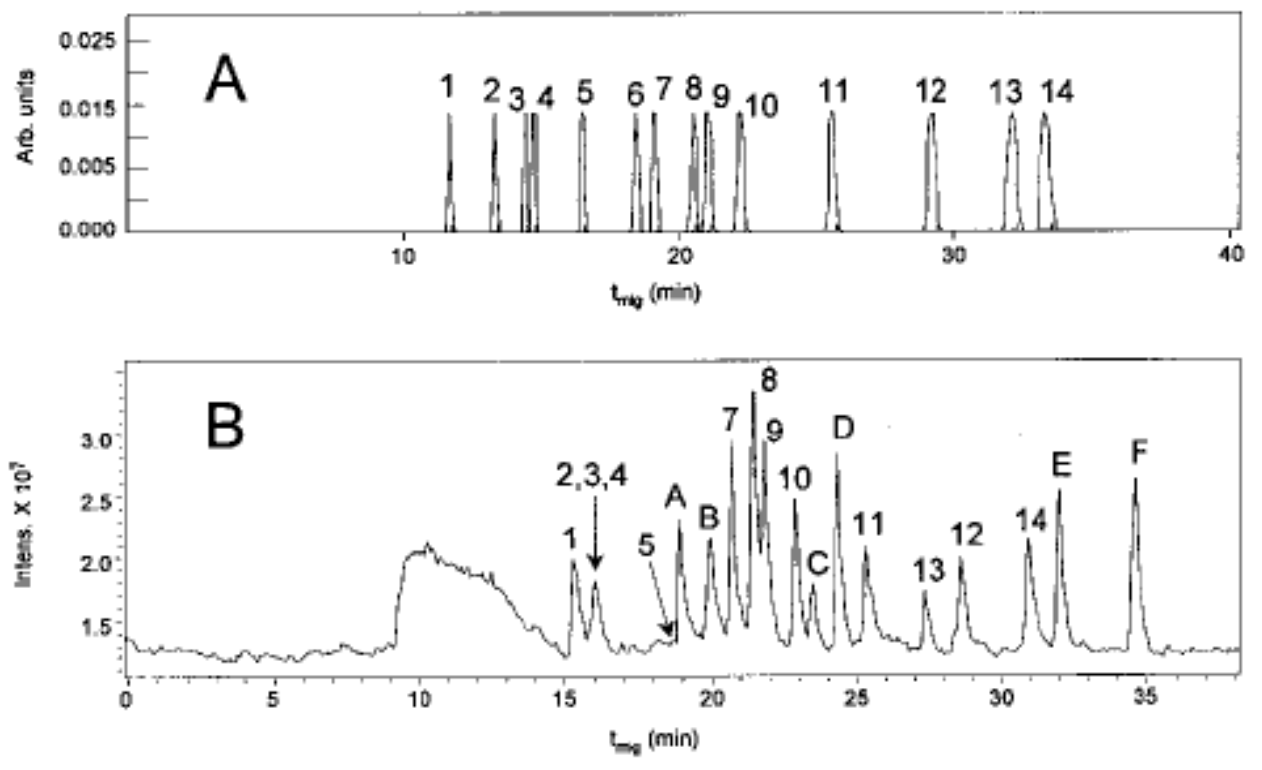

Figure 2. 


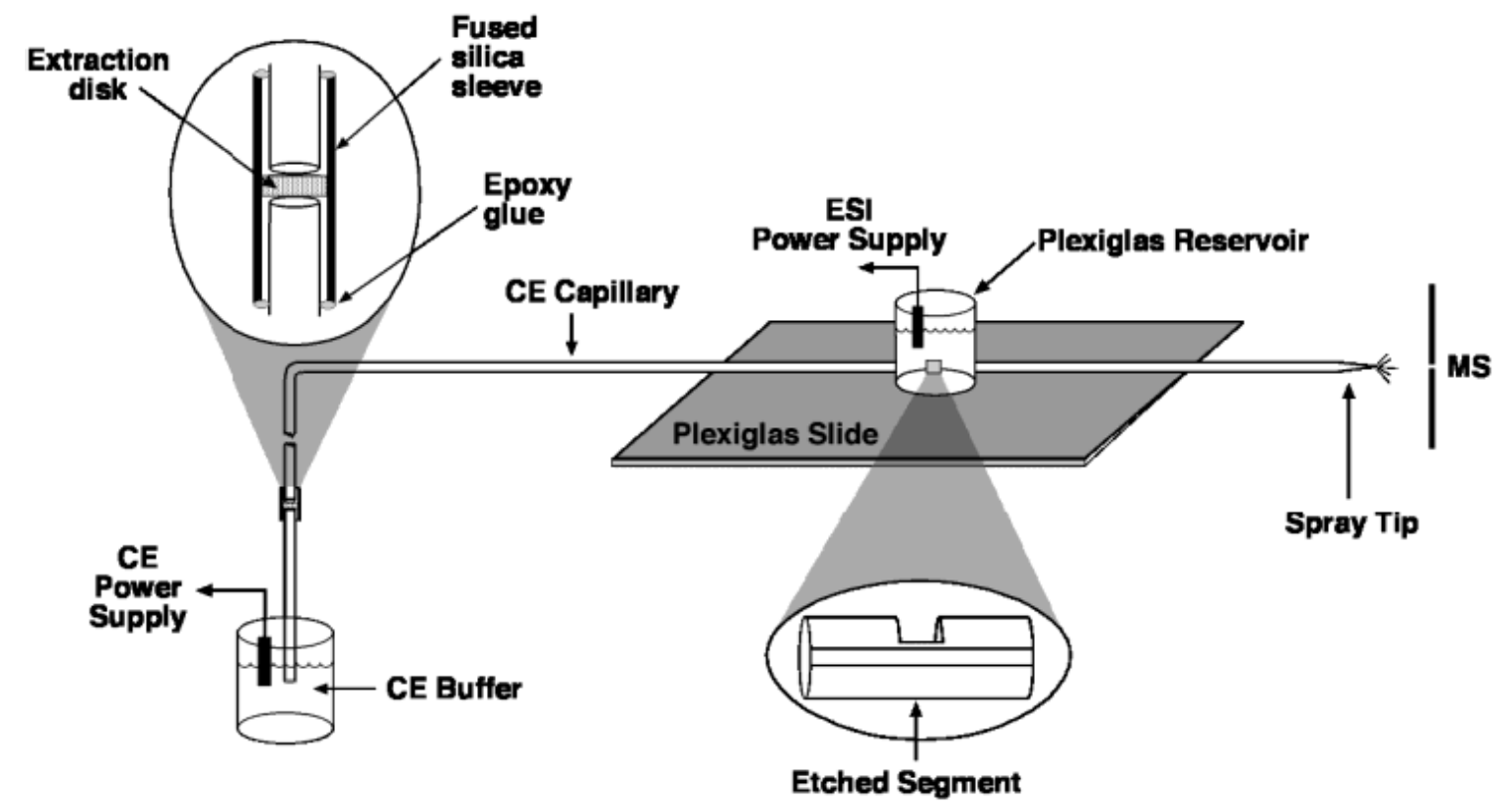

Figure 3. 


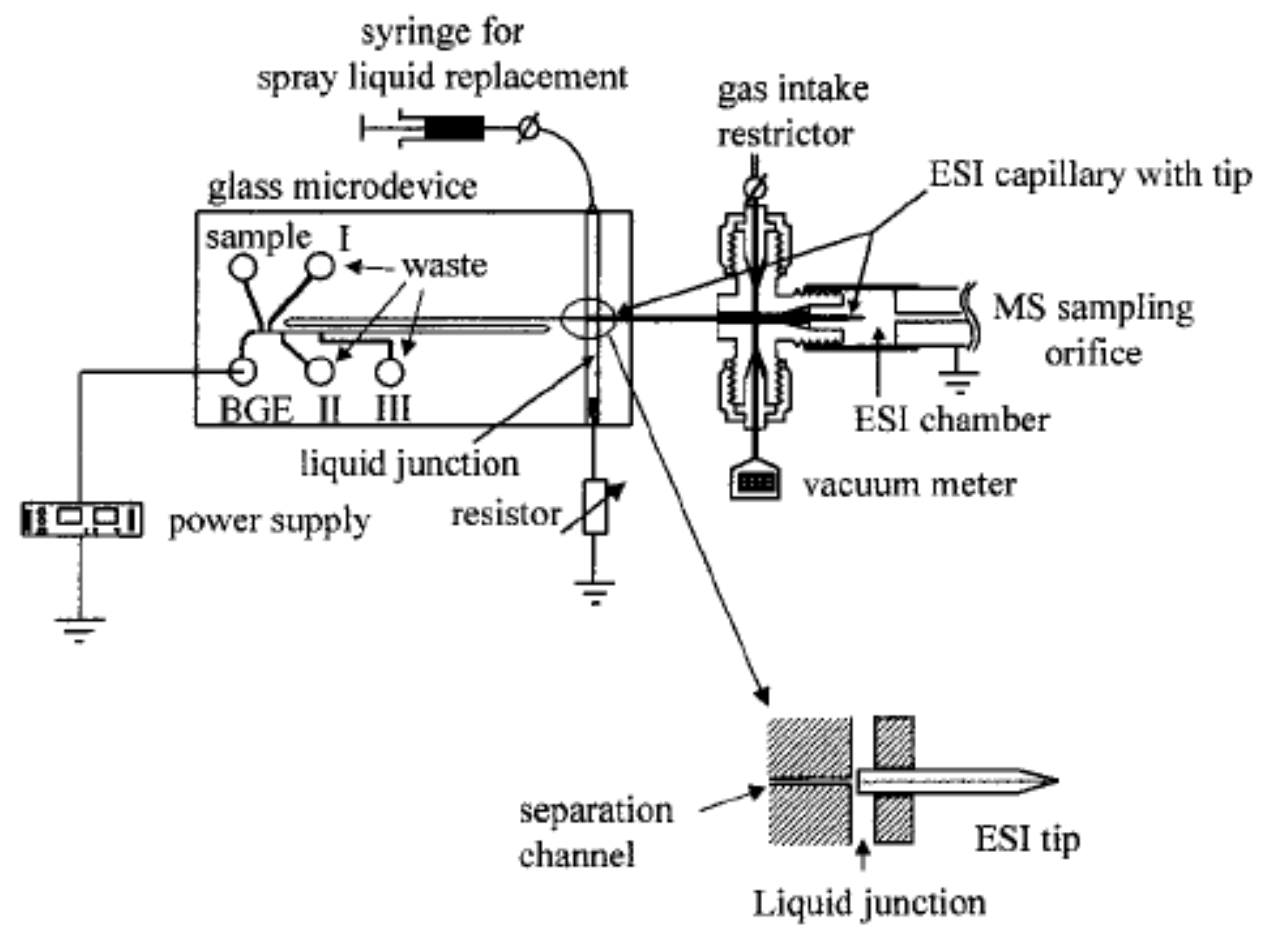

Figure 4. 


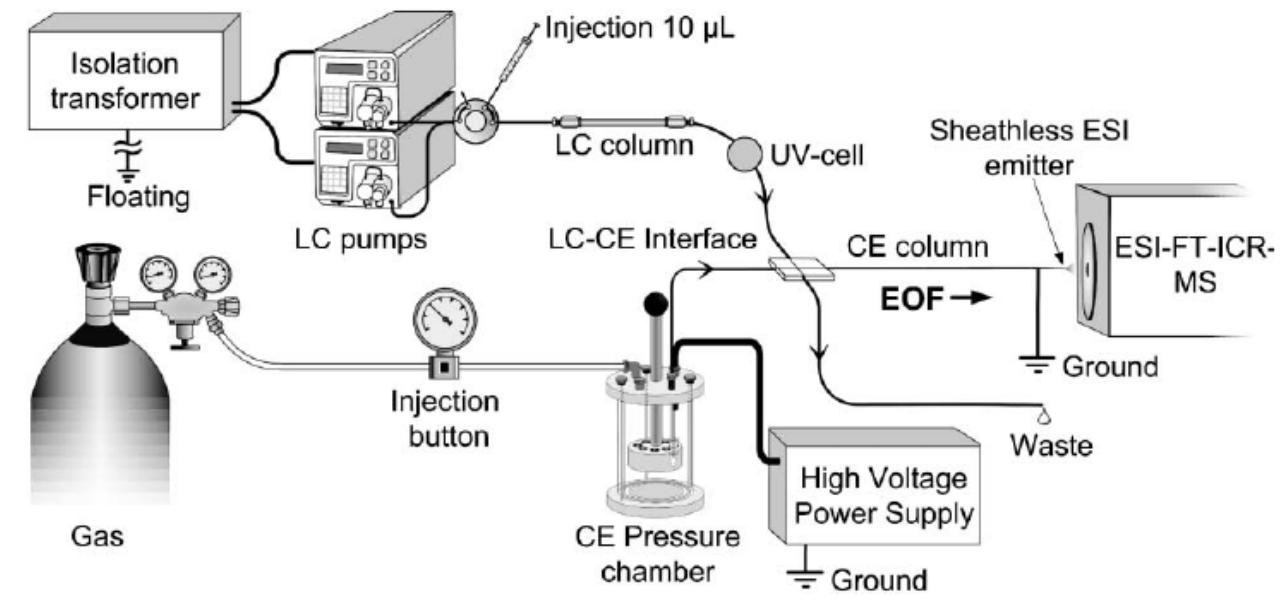

Figure 5. 